\title{
IPBES-6: the best plenary yet?
}

\author{
Peter Bridgewater $^{1,2} \cdot$ Dirk S. Schmeller ${ }^{3,4}$
}

Received: 26 April 2018 / Accepted: 24 May 2018 / Published online: 28 May 2018

(C) Springer Science+Business Media B.V., part of Springer Nature 2018

\begin{abstract}
The Intergovernmental Science-Policy Platform for Biodiversity and Ecosystem Services (IPBES) held its 6th plenary session in Medellin (Colombia) during March 2018. Several assessments were due for acceptance by the plenary. We here give news from the plenary and the platform, sketch out important key messages from the regional assessments as well as of the global thematic assessment on land degradation and restoration. We further give an outlook on the work ahead and potential for contributions from the scientific community to the important work of IPBES.
\end{abstract}

Keywords IPBES $\cdot$ Science-Policy $\cdot$ Assessments $\cdot$ Scientific contributions

\section{News from the plenary and the platform}

The Intergovernmental Science-Policy Platform for Biodiversity and Ecosystem Services (IPBES) held its 6th plenary session (IPBES-6) in Medellin (Colombia) during March 2018. For all those present, the atmosphere was generally calmer, collegiate, and more upbeat than previous plenaries (Bridgewater 2017; Schmeller and Bridgewater 2016; Schmeller et al. 2017). Likely due to the improvements in the IPBES budget, and because the plenary had five new assessments to accept. These five assessments are the result of the work of 450 experts and a considerable amount of comments from governments and IPBES

Communicated by David Hawksworth.

Dirk S. Schmeller

ds@die-schmellers.de

1 Institute for Applied Ecology, University of Canberra, Canberra, Australia

2 Centre for Museums and Heritage, Australian National University, Canberra, Australia

3 Department of Conservation Biology, Helmholtz Center for Environmental Research - UFZ, Leipzig, Germany

4 EcoLab, Université de Toulouse, UPS, INPT, Toulouse, France 
observers, indicating key concerns. The summaries for policymakers of these assessments needed review and approval, which led to a seriously overcrowded timetable. Many sessions ran way over time with participants working together to improve the summaries and meet artificial deadlines of press conferences at which the assessments were to be launched to the wider world.

The growing interest in the work of IPBES is also reflected in the increasing number of states becoming IPBES members. In the last interplenary three new members joined IPBES, Armenia, Bulgaria and Paraguay, increasing the number of member states to 129, with attendance at IPBES-6 from 86 of them. The strict IPBES rules about credentials left 10 member deemed observers, alongside other observer nations and groups, like the OpenEnded Network of IPBES Stakeholders (a full list can be found here https://www.ipbes.net/ accredited-organisations). Observers have the right to observe during the plenary sessions (=the assembly of member states), but are allowed to intervene only if the Chair agrees, and their ideas accepted only if supported by a platform member. Apart of the administrative body of IPBES (the bureau), the Multidisciplinary Expert Panel (MEP) is the scientific advisory board consisting of 25 experts, 5 from each UN-region). The MEP was criticized in the past due to its male dominance and despite elections of new members of the Multidisciplinary Expert Panel (MEP), the panel remains very male dominated. However, one important change of MEP was that some new members had indigenous and local knowledge (ILK), which will help the MEP to adopt a broader perspective in IPBES' future work.

The highlight of IPBES-6 was the acceptance of four regional assessments on status and trends in biodiversity for Europe and central Asia, Asia-Pacific, Americas and Africa regions, as well as a global thematic assessment on land degradation and restoration. Each assessment had an associated Summary for Policy makers (SPM), and all were approved, after detailed review by the plenary. Details may be found at IPBES (2018). Although each assessment took all the allocated time plus an additional 3-h slot, none finished on time. For the regional assessments, Asia-Pacific finished first, followed by the Americas, Africa and at 03:30 am Europe and Central Asia. The land degradation assessment approval process also ran well over the allotted time, taking an extra day. Partly this time run-over was due to a continuing lack of appreciation for what IPBES members should do regarding assessment acceptance and SPM approval. Future processes should aim to become more streamlined with increased emphasis on sticking with text provided by Authors, unless there are serious factual or policy errors or foci. But many delegations appeared to treat this whole process as a negotiating event rather than a "spit and polish" editing one, ensuring the evidence to support policy development and implementation was crisp, correct and understandable.

Part of the reason three of the regional assessments ran way over time was due to arguments about the relative merits of ecosystem services versus the evolving concept of "natures contributions to people" (Díaz et al. 2018; Pascual et al. 2017), which is also heatedly discussed in the scientific community (Braat 2018). Clearly much more work is needed on these issues, and while there is little doubt IPBES is contributing to this debate, the wider scientific community must be involved to make this a credible and legitimate process. European countries were quite firm on not wanting to dilute the ecosystem services concept, arguing its policy framing was now firmly accepted and well-known (Bouwma et al. 2017). Countries in the Asia-Pacific, African and Americas regions were much more comfortable with the less economically-focussed "natures contributions to people". Of course, the irony is that neither ecosystem services nor nature's contributions to people deal with people's contribution to nature, or the shaping of landscapes over long periods 
of time by human interventions, and through the reinforcing and feedback loops between biological and cultural diversity. This issue is one that needs better clarification before the Global Assessment is discussed at IPBES-7.

\section{Key messages from the regional assessments}

The key messages from the four regional assessments had commonalities, but also clear differences. An important and common theme was the richness of biodiversity and ecosystem services found in each region, with varying emphasis on the links between biodiversity and the richness of indigenous and local knowledge. Europe and central Asia had the least emphasis on this point, Africa perhaps the most. All pointed to the need to maintain the current diversity of species, genes, ecosystems, and services they contribute to maintaining human well-being. There were arguments about just what human well-being means, and the linking of biological and cultural diversity is still very much a work in progress (Plieninger et al. 2018). Yet, perhaps for the first time in international discussions, this link was made clear and explicit in these regional assessments.

Another important common point, albeit differentially expressed, was the link between conservation and wise management of biodiversity and the ability to undertake sustainable development. The Sustainable Development Goals made a number of appearances in the key messages-for example in the Europe and Central Asia text "The continuation of past and present (negative) trends in drivers to, and beyond, 2030 (as represented in businessas-usual scenarios) will inhibit the widespread achievement of goals similar to and including the Sustainable Development Goals (SDGs). Future scenarios that focus on achieving a balanced supply of nature's contributions to people and that incorporate a diversity of values are more likely to achieve the majority of such goals". The Americas Assessment notes "Continued loss of biodiversity could undermine the achievement of some of the Sustainable Development Goals, as well as some international climate-related goals, targets and aspirations. "And in Africa-Africa's unique and abundant biodiversity is an asset for the achievement of the Sustainable Development Goals and can be sustainably and equitably used to reduce inequality and poverty on the continent". Finally, for the Asia-pacific region "Continuing economic growth and infrastructure development, in some sub-regions, are required for achieving the Sustainable Development Goals of eradicating poverty and hunger, and ensuring energy, health, and water security, but need to be pursued in harmony with nature if they are to be sustainable." This similar set of conclusions, but with definite differences, make the important point that maintenance of biodiversity globally is needed to support achievement of all the SDGs, not just the two that deal specifically with biodiversity.

An irritating feature of the assessments was that while reporting on similar themes they did not use the same format in developing the SPMs. Thus it was difficult to make crossregional comparisons and will possibly not make it so easy to integrate the conclusions from these regional and sub-regional assessments into the Global Assessment, due for review at IPBES-7.

A specific key message on Coral reefs was included in the Asia-Pacific SPM "Coral reefs are of critical ecological, cultural and economic importance, supporting the livelihoods of hundreds of millions of people in the Asia-Pacific region and beyond through vital and valuable ecosystem services such as food security or coastal protection, and are under serious threat." The SPM also notes the connectivity between corals, mangroves, 
sea-grass beds as a coastal system complex, and stresses the need to maintain connections to ensure sustainability.

There are some statements in the SPMs that do stretch credulity. For example, in the Asia-Pacific assessment, as approved by the plenary, it was noted that "Coastal and marine ecosystems are threatened due to unsustainable aquaculture practices, overfishing and destructive harvesting practices. It is projected that if current fishing practices continue, there will be no exploitable fish stocks by 2048 . The intertidal zones are also rapidly deteriorating owing to human activities (established but incomplete)". This statement was perhaps an example of an alarmist statement taken too far, and was subsequently corrected by the authors to read: "Coastal and marine ecosystems are threatened due to unsustainable aquaculture practices, overfishing and destructive harvesting practices. It is projected that if current unsustainable fishing practices continue, there could be no exploitable fish stocks left by as early as 2048. The intertidal zones are also rapidly deteriorating owing to human activities (established but incomplete)" is perhaps an example of an alarmist statement taken too far. Bartley (pers comm) reports that "the 2048 prediction comes from Worm (Worm et al. 2006), itself subject of considerable subsequent debate, that was cited in a newspaper book review (Renton 2008), and then uncritically reused in the IPBES trends paper". This is an example where headline-grabbing statements, uncritically filtered from assessment to SPM, need more careful quality control than the timetable evidently allowed. The subsequent correction by the authors was appropriate, but the document as such has therefore not been fully and properly approved by plenary. Correctness and sobriety will be how IPBES assessments and SPMs will be judged by the wider community.

As with the regional assessments the SDGs feature in the land degradation and restoration assessment SPM- "Avoiding, reducing and reversing land degradation is essential for reaching the majority of the Sustainable Development Goals and would deliver co-benefits for nearly all of them". Other key messages addressed the links with climate change and land degradation, and the degradation problems exacerbated by unsustainable development, and that the benefits of avoiding land degradation fare outweigh the costs. A startling figure produced by the assessment is that over 3 billion people globally are already affected by degradation to some degree-and the expectation is that such a number will only increase (IPBES 2018). Further, the land degradation and restoration assessment delivered the key message that "Timely action to avoid, reduce and reverse land degradation can increase food and water security, can contribute substantially to the adaptation and mitigation of climate change and could contribute to the avoidance of conflict and migration". Links between climate change and degradation-often self-reinforcing-are well dealt with in the assessment. The assessment makes a clear case for further work on a range of issues-from climate change impacts to integrating conventional science and indigenous and local knowledge-will be needed to further enable evidence-based decisions to help to avoid and reduce land degradation and promote and enable restoration.

\section{Pending assessments}

A number of assessments were frozen at IPBES-5 due to budget uncertainties. A better budgetary position enabled a green light for three new assessments:

- a thematic assessment of the sustainable use of wild species; 
- a methodological assessment regarding the diverse conceptualization of multiple values of nature and its benefits; and

- a thematic assessment of invasive alien species.

It was finally agreed that the assessments dealing with sustainable use of wild species and diverse conceptualization of multiple values of nature and its benefits would commence in the current year, with the assessment on invasive alien species next year-providing the better status of the budget is maintained. The sustainable use may start more slowly as a workshop of Multilateral Environment Agreements/UN bodies and a few authors will start the process by compiling a full resource of what's actually been or being done across the Multilateral Environment Agreement landscape.

\section{Review of the platform}

It had been discussed during IPBES-5 that a review process of the platforms effectiveness be carried out during 2018, subject to budgetary requirements (Schmeller et al. 2017). Two processes were suggested-an internal review and and an external panel, managed by an external body and not the IPBES secretariat. The internal review was held during 2017 involving the secretariat and major organs of the platform. The results (predictably) were of the "nothing to see here" style, with some minor tweaks suggested for improvement. The external review ${ }^{1}$ will be managed by ICSU, and has funds for two face-to-face meetings, to be linked with the MEP/Bureau timetabled meetings. How the review process is designed will be quite critical to its success. Suggestions from the wider academic community could be relayed via the national focal points, the Open-Ended Network of IPBES Stakeholders or the IPBES secretariat.

While building on the internal review the external process will doubtlessly be more forensic. One area of concern will be how the impact and effectiveness of IPBES is measured. Currently, a main metric for success is, as with the pollination assessment, column inches or numbers of articles relating to or reporting on the assessment. While interesting as an expression of interest at a point in time there needs to be a better developed "theory of change" to see the effect of the assessments on biodiversity conservation and management-a major challenge for the review team.

\section{Development of a second work programme and participation}

A mechanism for the future work programme and participation was devised which tries to draw advice and suggestions from members. The idea that it would become a rolling programme, rather than a second programme, seemed to gain wide acceptance, as did a possible meeting schedule for the plenary at 18-month intervals, rather than annually. These ideas will be offered to the external review for consideration.

An important part of the current and the next IPBES work programme will be scenarios and models. The global academic community was invited through a joint call of the global Belmont Forum and the European BiodivERsA ERANET to contribute to this IPBES work. The call was a direct results from suggestions of an IPBES expert group

\footnotetext{
${ }^{1}$ Disclosure: one of the authors (PB) is a member of the external review panel.
} 
identifying important knowledge gaps. A total of $€ 25$ million were dedicated to this call and the funders are currently assessing and selecting projects from more than 100 submitted proposals. The proposals will also foster the second phase of the expert group's work, focusing on sustaining support for the use of scenarios and models in IPBES assessments. The projects hopefully will also catalyse the development of the next generation of scenarios and models by the wider scientific community and IPBES stakeholders through a participatory and inclusive approach. It needs to be seen how the different projects envisage such an approach, but possibilities to contribute and participate should be manifold for our readers and the scientific community. We reiterate that possibilities to actively contribute and participate in the IPBES work are highly desirable and that e.g. the Open-Ended Network of IPBES stakeholders is an important entry point for interested colleagues (Schmeller et al. 2017).

\section{References}

Bouwma I, Schleyer C, Primmer E, Winkler KJ, Berry P, Young J, Carmen E, Špulerová J, Bezák P, Preda E (2017) Adoption of the ecosystem services concept in EU policies Ecosystem Services

Braat LC (2018) Five reasons why the Science publication "Assessing nature's contributions to people" (Diaz et al. 2018) would not have been accepted in Ecosystem Services Ecosystem Services 30:A1-A2 doi:https://doi.org/10.1016/j.ecoser.2018.02.002

Bridgewater P (2017) The intergovernmental platform for biodiversity and ecosystem services (IPBES) - a role for heritage? Int J Herit Stud 23:65-73. https://doi.org/10.1080/13527258.2016.1232657

Díaz S, Pascual U, Stenseke M, Martín-López B, Watson RT, Molnár Z, Hill R, Chan KM, Baste IA, Brauman KA (2018) Assessing nature's contributions to people. Science 359:270-272

IPBES (2018) https://www.ipbes.net/outcomes acessed 26/04/2108

Pascual U, Balvanera P, Díaz S, Pataki G, Roth E, Stenseke M, Watson RT, Dessane EB, Islar M, Kelemen E (2017) Valuing nature's contributions to people: the IPBES approach. Curr Opin Environ Sustain 26:7-16

Plieninger T, Kohsaka R, Bieling C, Hashimoto S, Kamiyama C, Kizos T, Penker M, Kieninger P, Shaw BJ, Sioen GB (2018) Fostering biocultural diversity in landscapes through place-based food networks: a "solution scan" of European and Japanese models. Sustain Sci 13:219-233

Renton A (2008) No net gain from empty seas. Retrieved from http://www.guardian.co.uk/books/2008/ jul/13/scienceandnature.features

Schmeller DS, Bridgewater P (2016) The Intergovernmental Platform on Biodiversity and Ecosystem Services (IPBES): progress and next steps. Biodivers Conserv 25:801-805. https://doi.org/10.1007/s1053 1-016-1095-9

Schmeller DS, Niemelä J, Bridgewater P (2017) The Intergovernmental Science-Policy Platform on Biodiversity and Ecosystem Services (IPBES): getting involved. Biodivers Conserv 26:2271-2275. https:// doi.org/10.1007/s10531-017-1361-5

Worm B, Barbier EB, Beaumont N, Duffy JE, Folke C, Halpern BS, Jackson JBC, Lotze HK, Micheli F, Palumbi SR, Sala E, Selkoe KA, Stachowicz JJ, Watson R (2006) Impacts of biodiversity loss on ocean ecosystem services. Science 314:787-790. https://doi.org/10.1126/science.1132294 